Zhang, H., Huang, R., Zhang, Y., Buhalis, D., 2020, Cultural ecosystem services evaluation using geolocated social media data: a review, Tourism Geographies https://doi.org/10.1080/14616688.2020.1801828

Zhang, H., Huang, R., Zhang, Y., Buhalis, D., 2020, Cultural ecosystem services evaluation using geolocated social media data: a review, Tourism Geographies https://doi.org/10.1080/14616688.2020.1801828

\title{
National park visitors' car-use intention: A norm-neutralization model
}

Abstract: Reducing private car use is an efficient way to promote the sustainable development of national parks. However, many visitors persist in using their cars, even when they are aware of the environmental damage it causes. This study proposed a norm-neutralization model to investigate why national park visitors persist in car-based trips by partially integrating the theory of planned behavior, the norm-activation model, and neutralization theory. The results indicated that neutralization techniques can effectively reduce the effects of social norms and attitudes on car-based trip intention in a conflicting-norm context. The strongest predictors of behavior intention were attitudes toward the behavior while neutralization techniques were the second strongest. The effect of pro-driving norms showed a significant reduction when neutralization techniques were added, but pro-environmental norms did not have a significant effect on behavior intention. Practical and theoretical implications, as well as directions for future research, are discussed.

Keywords: norm-neutralization model; pro-driving norms; pro-environmental norms; neutralization techniques; car-based trip; national parks

\section{Introduction}

Increased disposable income has boosted the growth of private car ownership and car-based trips in developing countries. By March 2017, the number of private cars in China had risen to over 150 million (China Transport Administration of Public Security Ministry, 2017). The car is becoming the main travel mode among Chinese for short-haul holiday trips. According to a report by the China Tourism Academy, there were 32.13 million car-based tourists during the eight-day super holiday for the 2017 National Day and Mid-Autumn Festival (China Tourism Academy, 2017). Private cars provide many benefits for travelers, including benefits that are functional (e.g., convenient), psychological (e.g., pleasurable), and social (e.g., self-image boosting) (Ellaway, Macintyre, Hiscock, \& Kearns, 2003; Uba \& Chatzidakis, 2016), thus promoting the formation of pro-driving norms.

However, private car use is also a major contributor to overall carbon emissions from the transport sector (Klockner \& Friedrichsmeier, 2011). Transportation dominates the energy bills of domestic and international tourists, accounting for $65-73 \%$ of total energy use (Becken, Simmons, \& Frampton, 2003; Filimonau, Dickinson, \& Robbins, 2014; Lin, 2010; Martín-Cejas, 2015). Aside from carbon emissions and energy use, car-based trips create many other environmental problems, especially in natural areas, such as negative effects on wild animals and plants, noise, and crowding (Gao, Huang, \& Zhang, 2016; Wolf \& Croft, 2010; Beunen, Regnerus, \& Jaarsma, 2008). During each Golden Week in China, it is common for the large number of private cars to cause traffic jams and pollution on highways and in tourism areas. Such consequences have aroused public environmental awareness. Rapidly developing high-speed railways are providing alternatives for short- and medium-length travel. In tourism areas, tourists can choose more sustainable travel modes, such as public buses, shared bicycles, and electric vehicles (Nakamura \& Abe, 2016). Nevertheless, it remains difficult to change or reduce car use among tourists (Davies \& Weston, 2015). 
Zhang, H., Huang, R., Zhang, Y., Buhalis, D., 2020, Cultural ecosystem services evaluation using geolocated social media data: a review, Tourism Geographies https://doi.org/10.1080/14616688.2020.1801828

The decision to use a car depends on various factors. Existing research has explored car-use behavior in daily life, revealing a complex range of reasons, including those that are instrumental or utilitarian, psychosocial, affective, or situational (Bamberg, Fujii, Friman, \& Garling, 2011; Mackett, 2003; Uba \& Chatzidakis, 2016). Worldwide, the private car is the major travel and recreational mode for national park visitors (Connell \& Page, 2008). While some studies have investigated the ecological implications of bus transit services provided by national parks (Mace, Marquit, \& Bates, 2013; Monz, D’Antonio, Lawson, Barber, \& Newman, 2016), few studies have examined why national park visitors persist in using cars. Therefore, the present study aimed to develop a norm-neutralization model to address that question and show the relative importance of different determinants or antecedents. This model partially integrates the theory of planned behavior (TPB), the norm-activation model (NAM), and neutralization theory. It proposes that social norms (including pro-driving and pro-environmental norms) are determinants of car-based-trip intention. Here, pro-driving norms are impetus factors while pro-environmental norms are hindering factors. Positive attitudes toward car-based trips are important contributors to car-use intention. The perceived benefits of car use promote the formation of pro-driving norms and positive attitudes toward car-based trips. Meanwhile, the perceived negative effects of car use activate pro-environmental norms and inhibit positive attitudes toward car-based trips. Various neutralization techniques (e.g., denial of responsibility) are used to reduce the cognitive dissonance caused by different kinds of norms and justify car-use behaviors. For this study, this model was tested using a pilot national park in China.

It should be noted that the model does not include perceived behavioral control and ascription of responsibility, as in TPB and NAM. There are two reasons for this. First, this study aimed to propose a normneutralization model that emphasizes the effects of two conflicting norms and neutralization techniques on behavior intention; it did not seek to test a fully integrated TPB and NAM model. Second, this study viewed the perceived benefits and perceived negative influences of car use as two opposite effects that promote or activate pro-driving norms and pro-environmental norms, respectively. Prior research has also suggested a parallel model for NAM that assumes that awareness of consequences has a direct effect on personal norms (Harland, Staats, Wilke, 2007; Zhang, Geng, \& Sun, 2017). Accordingly, the present study assumed that the perceived negative influences of car use had a direct effect on pro-environmental norms.

This study makes several contributions to the existing literature on car use and pro-environmental behavior. First, in the field of tourism and national park research, this study is the first attempt to focus on a conflicting-norm context by integrating pro-driving and pro-environmental norms into one model. Prior pro-environmental behavior models have viewed social norms as important antecedents of behavior intentions; both subjective norms and personal norms are pro-environmental norms in nature. In some contexts, however, tourists likely face conflicting norms simultaneously, as with pro-driving norms. Therefore, this study extends previous research from focusing on only a single type of norm (e.g., pro-environmental norms) to focusing on pro-environmental norms as well as other conflicting norms, such as pro-driving norms. This logic can be extended to other contexts beyond car use. Second, this is the first attempt to integrate neutralization theory into a pro-environmental behavior model, which is helpful for explaining how tourists justify their norm-violating behaviors. This study compared a model that included neutralization techniques with one that did not include neutralization techniques; in this way, the role of neutralization techniques was demonstrated. Third, this study explored the role of the perceived personal benefits and perceived environmental costs of car-based trips in the formation of pro-driving norms, pro-environmental norms, and attitudes toward behaviors; this is helpful for understanding the formation processes of norms and attitudes. Lastly, based on prior qualitative and quantitative research in other fields, this study developed a perceived benefit scale, pro-driving scale, and neutralization techniques scale that can be used in future proenvironmental behavior research. 
Zhang, H., Huang, R., Zhang, Y., Buhalis, D., 2020, Cultural ecosystem services evaluation using geolocated social media data: a review, Tourism Geographies https://doi.org/10.1080/14616688.2020.1801828

\section{Theoretical foundation and hypotheses}

\subsection{Social norms and pro-environmental behavior}

The social norm is an important concept that originated in sociology. Over time, it has been used to explain a wide range of behaviors, including pro-environmental behavior and travel behavior (Donald, Cooper, \& Conchie, 2014; Riggs, 2017). Most studies distinguish descriptive norms from injunctive norms (Farrow, Grolleau, \& Ibanez, 2017). Descriptive norms refer to perceptions of "normal" behavior, or what most people do, whereas injunctive norms refer to what most people approve or disapprove of doing (i.e., pre- or proscriptive norms). Thøgersen (2006) proposed a norm taxonomy according to the level of norm internalization, including descriptive norms, subjective social norms, introjected norms, and integrated norms. The latter three norms are assigned to injunctive norms. Subjective social norms describe what other people think a person should do. This category of norm is included in the TPB (Ajzen, 1991). As internalization levels increase, social norms manifest as personal norms, including introjected and integrated personal norms. An integrated personal norm is one that is deeply internalized in an individual's values and beliefs whereas an introjected norm is superficially internalized. Conforming to or violating introjected norms will cause self-imposed feelings of pride or guilt. Personal norms have been included in the NAM (Schwartz, 1977) and the value-belief-norm theory (VBN, Stern, 2000).

TPB, NAM, and VBN have been widely used to explain a variety of pro-environmental behaviors in tourism and hospitality studies. In those models, norms and attitudes are two important antecedents of pro-environmental behavior. Subjective norms and personal norms are often included simultaneously in many integrated models. The former is operationalized as perceptions of the influence of important others-namely, whether important others think one should perform a particular behavior (e.g., stay at a green hotel when traveling) or a general proenvironmental behavior (Goh, Ritchie, \& Wang, 2017; Han, 2015). The latter is operationalized as a sense of obligation to perform pro-environmental actions (e.g., select an eco-friendly restaurant) (Gao et al., 2016; Kim, Njite, \& Hancera, 2013; Kiatkawsin \& Han, 2017). While these two kinds of norms have been shown to have significant effects on pro-environmental behaviors, their direct-effect sizes are different (Table 1). A number of studies by Han and his colleagues have shown that personal norms have a stronger effect on pro-environmental behaviors than subjective norms (Han, 2014, 2015; Han, Jae, \& Hwang, 2016; Kiatkawsin \& Han, 2017). Those findings corroborate an earlier study on the use of public transportation (Bamberg, Hunecke, \& Blobaum, 2007). However, researchers have argued that subjective norms contribute to the formation of personal norms and have indirect effects on pro-environmental behaviors through personal norms and attitudes (Bamberg et al., 2007; Han, 2015; Han, Jae, \& Hwang, 2016; Kim, Ham, Yang, \& Choi, 2013).

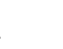

4


Zhang, H., Huang, R., Zhang, Y., Buhalis, D., 2020, Cultural ecosystem services evaluation using geolocated social media data: a review, Tourism Geographies https://doi.org/10.1080/14616688.2020.1801828

131

132

133

Table 1. The influence of norms and attitudes on PEB in tourism and hospitality studies (direct effect)

\begin{tabular}{|c|c|c|c|c|c|}
\hline Author(s) & $\mathrm{SN} \rightarrow \mathrm{PEB}$ & PN $\rightarrow$ PEB & $\mathrm{AT} \rightarrow \mathrm{PEB}$ & PEB & Other variables \\
\hline $\begin{array}{l}\text { Kim \& Han } \\
(2010)\end{array}$ & $\beta=0.09^{*}$ & & $\beta=0.46^{* *}$ & $\begin{array}{l}\text { Pay conventional } \\
\text { hotel prices }\end{array}$ & $\begin{array}{l}\text { Other variables in TPB, } \\
\text { environmental concerns, } \\
\text { perceived customer } \\
\text { effectiveness, environmentally } \\
\text { conscious behaviors }\end{array}$ \\
\hline $\begin{array}{l}\text { Kim, Njite, } \\
\text { \& Hancera } \\
(2013)\end{array}$ & $\beta=0.43^{* *}$ & & $\beta=0.29 * *$ & $\begin{array}{l}\text { Select an eco- } \\
\text { friendly restaurant }\end{array}$ & $\begin{array}{l}\text { Other variables in } \mathrm{TPB}, \\
\text { anticipated regret }\end{array}$ \\
\hline $\begin{array}{l}\text { Kim, Han, } \\
\text { Yang, \& } \\
\text { Choi (2013) }\end{array}$ & $\beta=0.06$ & & $\beta=0.83 * * *$ & $\begin{array}{l}\text { Nutritional labeling } \\
\text { use }\end{array}$ & Other variables in TPB \\
\hline $\begin{array}{l}\text { Chen \& } \\
\text { Tung (2014) }\end{array}$ & $\beta=0.34 * * *$ & $\beta=0.13 * *$ & $\beta=0.32 * * *$ & Visit green hotels & $\begin{array}{l}\text { Environmental concern, } \\
\text { perceived behavioral control }\end{array}$ \\
\hline $\operatorname{Han}(2014)$ & $\beta=0.24^{* * *}$ & $\beta=0.59^{* * *}$ & $\beta=0.17 * *$ & $\begin{array}{l}\text { Environmentally } \\
\text { responsible } \\
\text { convention } \\
\text { attendance }\end{array}$ & $\begin{array}{l}\text { Other variables in VAM, } \\
\text { attitude, anticipated feeling of } \\
\text { pride and guilt }\end{array}$ \\
\hline $\operatorname{Han}(2015)$ & $\beta=0.20^{* *}$ & $\beta=0.36^{* *}$ & $\beta=0.28 * *$ & $\begin{array}{l}\text { Stay at a green } \\
\text { hotel }\end{array}$ & $\begin{array}{l}\text { Other variables in TPB and } \\
\text { VBN }\end{array}$ \\
\hline $\begin{array}{l}\text { Han \& } \\
\text { Hwang } \\
(2015)\end{array}$ & & $\beta=0.60^{* *}$ & & $\begin{array}{l}\text { Attend an } \\
\text { environmentally } \\
\text { responsible } \\
\text { convention }\end{array}$ & $\begin{array}{l}\text { Cognitive loyalty, affective } \\
\text { loyalty, action loyalty, social } \\
\text { norm }\end{array}$ \\
\hline $\begin{array}{l}\text { Han, } \\
\text { Hwang, } \\
\text { Kim \& Jung } \\
(2015)\end{array}$ & & $\beta=0.34 * *$ & $\beta=0.13^{*}$ & $\begin{array}{l}\text { Revisit an } \\
\text { environmentally } \\
\text { responsible hotel }\end{array}$ & $\begin{array}{l}\text { Other variables in VAM, past } \\
\text { behavior, green activity, } \\
\text { subjective norm, positive } \\
\text { anticipated emotion, negative } \\
\text { anticipated emotion }\end{array}$ \\
\hline $\begin{array}{l}\text { Han, Jae, \& } \\
\text { Hwang } \\
\text { (2016) }\end{array}$ & & $\beta=0.55^{* *}$ & & $\begin{array}{l}\text { Environmentally } \\
\text { responsible cruise }\end{array}$ & $\begin{array}{l}\text { Other variables in TPB, VAM, } \\
\text { and goal-directed behavior } \\
\text { model }\end{array}$ \\
\hline $\begin{array}{l}\text { Untaru et al. } \\
\text { (2016) }\end{array}$ & $\beta=0.13^{* *}$ & & $\beta=0.81^{* *}$ & $\begin{array}{l}\text { Conserve water in a } \\
\text { lodging context }\end{array}$ & $\begin{array}{l}\text { Environmental concern, water } \\
\text { conservation activities in } \\
\text { everyday life }\end{array}$ \\
\hline $\begin{array}{l}\text { Goh, } \\
\text { Ritchie, \& } \\
\text { Wang } \\
(2017)\end{array}$ & $\beta=0.21^{* *}$ & & $\beta=0.18^{* *}$ & $\begin{array}{l}\text { Venturing off-trail } \\
\text { behavior }\end{array}$ & $\begin{array}{l}\text { Other variables in TPB, } \\
\text { environmental value }\end{array}$ \\
\hline $\begin{array}{l}\text { Kiatkawsin } \\
\text { \& Han } \\
(2017)\end{array}$ & & $\beta=0.58^{* *}$ & & $\begin{array}{l}\text { Behave pro- } \\
\text { environmentally } \\
\text { while traveling }\end{array}$ & $\begin{array}{l}\text { Other variables in VBN and the } \\
\text { expectancy theory }\end{array}$ \\
\hline
\end{tabular}

Note: $\mathrm{SN}=$ subjective norm, $\mathrm{PN}=$ personal norm, $\mathrm{AT}=$ attitude, $\mathrm{PEB}=$ pro-environmental behavior; ${ }^{* *} \mathrm{p}<0.01$, $* * * \mathrm{p}<0.001$.

\subsection{Pro-driving norms, pro-environmental norms, and attitudes}

In addition to Thøgersen's (2006) taxonomic approach from an internalization perspective, different norms exist in different life domains or subculture groups. Sometimes, these norms are opposing or conflicting. For example, pro-driving and pro-environmental norms are two distinct and opposing sets of normative expectations that may influence car usage. In a study of university students' commuting behaviors, Uba and Chatzidakis (2016) suggested that pro-driving norms applied only to driving traditional cars, not sustainable cars (e.g., electronic cars). They argued that pro-driving norms were more prevalent among young adults as they came of age. In this context, car use is viewed as a symbolic tool for managing self-impressions, socialization, and identity building. Under the pressure of pro-driving norms, students may persist in car-use behavior, even if they are aware of the environmental 
Zhang, H., Huang, R., Zhang, Y., Buhalis, D., 2020, Cultural ecosystem services evaluation using geolocated social media data: a review, Tourism Geographies https://doi.org/10.1080/14616688.2020.1801828

damage caused by cars. Moreover, in developing countries, private car ownership is viewed as a symbol of status and prestige. In that context, car-based trips have been encouraged and advocated by most tourism destinations, local governments, and related industries. In China, the private car seems to have become the preferred travel mode for tourists. Aside from social benefits, such as status and prestige, psychological (e.g., the pleasure of driving) and utilitarian (e.g., convenience) benefits also facilitate the formation of pro-driving norms for Chinese tourists. To our knowledge, no previous study has provided an explicit definition of pro-driving norms or developed a scale to measure them. Following Thøgersen's (2006) taxonomy, this study views pro-driving norms as descriptive norms and defines them as one's perception that most other tourists choose private cars as their travel mode. Thus, the following hypotheses are proposed:

H1: The perceived benefits of car-based trips significantly facilitate the formation of pro-driving norms.

H2: Pro-driving norms have a significant and positive influence on the intention to take car-based trips.

The serious environmental consequences of human activity have aroused a general awareness of the need for environment protection. Many studies have explored ways to change individual behaviors or facilitate proenvironmental behaviors, including those related to car use. According to norm-activation theory, personal norms are the direct determinants of pro-social behaviors (including pro-environmental behaviors). Awareness of the negative consequences $(A C)$ of performing a particular behavior and the ascription of responsibility (AR) for those consequences activate personal norms (Schwartz, 1977). Schwartz and Howard (1981) defined personal norms as "moral obligations to perform or refrain from specific actions" (p. 191). Therefore, a personal norm in NAM is a kind of internalized injunction norm. In the context of pro-environmental behavior, personal norms refer to proenvironmental personal norms. Alternative terms are sometimes used, including "responsibility feeling," "perception of responsibility," and "responsibility" (Kaiser \& Shimoda, 1999; De Groot \& Steg, 2009; Gao et al., 2016). Gao et al. (2016) used the term "perception of responsibility" instead of personal norms, arguing that perception of responsibility can be a variable of personal norms. In addition, they operationalized responsibility as collective, rather than individual, which might be better suited to the Chinese tourism context.

Pro-environmental norms can assume three forms: subjective norms, personal norms (or moral norms), and descriptive norms. Donald et al. (2014) examined the influence of these three norms on transport modes used by commuters. They found that subjective norms influenced both car and public transport use behaviors indirectly through intention and habit. However, the effects of moral norms and descriptive norms were mixed. Specifically, they had no significant effects on car-use intention; only moral norms had a positive effect on public transport use intention. Other studies have likewise obtained mixed results. Harland, Staats, and Wilke (1999) found that moral norms were important factors for explaining using means of transportation other than cars, but Bamberg and Schmidt (2003) did not find moral norms to be very important for students' car use. Similarly, the explanatory power of subjective norms has also been mixed in related empirical studies (Armitage \& Conner, 2001; Kim, Ham, Yang \& Choi, 2013). Thus, several studies have used descriptive norms as alternative measurements of social pressure, examining the effects of descriptive norms on car-use behaviors. However, those results were mixed as well (Gardner \& Abraham, 2010; Rivis \& Sheeran, 2003; Donald et al., 2014). Aside from pro-environmental norms, the present study argues that descriptive measurements can also be used for pro-driving norms. The mixed results regarding different types of norms are mainly found in the context of using cars for commuting. Few studies have integrated personal moral norms and descriptive norms into a model. Even fewer have merged two conflicting norms (i.e., pro-driving and pro-environmental norms) into a model concerning tourists' travel mode choices. Thus, the following hypotheses are proposed:

H3: Awareness of the negative consequences of using a car has a positive effect on pro-environmental personal norm activation. 
Zhang, H., Huang, R., Zhang, Y., Buhalis, D., 2020, Cultural ecosystem services evaluation using geolocated social media data: a review, Tourism Geographies https://doi.org/10.1080/14616688.2020.1801828

H4: Pro-environmental personal norms have a negative effect on the intention to take car-based trips.

According to TPB and the expectancy-value model of attitudes (Fishbein \& Ajzen, 1975), attitudes develop from beliefs individuals hold about the objects of attitudes. Beliefs are related to the attributes or characteristics of the object, such as cost, comfort, and convenience. In the case of car-use behavior, these beliefs link the behavior to certain consequences (e.g., a car-based trip is convenient). If individuals believe a behavior can produce desirable consequences, favorable attitudes will form, and vice versa. Therefore, TPB emphasizes benefit and cost. When individuals face different behavior choices, they select the one with the most positive behavioral consequences. Bamberg and Schmidt (2003) explained university students' car-use behaviors using TPB, NAM, and the theory of interpersonal behavior (TIB) (Triandis, 1977, 1980). They found that behavior belief is a strong antecedent of attitudes toward behavior. Kim, E. et al. (2013) also supported this relationship. In the present study, the perceived benefits and perceived negative consequences of car-based trips were viewed as the positive and negative beliefs that may influence tourists' attitudes toward car use. The following hypotheses are proposed:

H5: The perceived benefits of car-based trips have a significant and positive influence on attitudes toward car-based trips.

H6: Awareness of the negative consequences of car use has a negative effect on attitudes toward car-based trips.

There is a lack of consensus on the predictive power of different components in TPB. Kim, Y. et al. (2013) found that subjective norms were the strongest predictive variables of ecological behavior intentions, compared to attitudes toward the behavior, perceived behavioral control, and anticipated regret. However, a meta-analysis by Armitage and Conner (2001) found that subjective norms were the weakest factors for behavior intention in TPB. As robust predictive variables of human behavior, attitudes toward behavior have been widely used to explain proenvironmental behavior. In some studies, however, attitudes had less predictive power than subjective norms (Kim, Y. et al., 2013; Han, 2014) (see Table 1). The present study tested the role of attitudes in explaining the intention to take car-based trips in a conflicting-norm context. The following hypothesis is proposed:

H7: Tourist attitudes toward car-based trips have a significant and positive effect on their intention to take car-based trips.

\subsection{Neutralization theory}

Neutralization theory, proposed by Sykes and Matza (1957), is an influential theory in the criminology and sociology of deviance for explaining norm-violating behaviors (Copes \& Williams, 2007). When individuals violate social norms, they may use neutralization techniques to justify their behavior and maintain a positive self-image or sense of self. Neutralization theory has been introduced into various other areas, such as norm-violating behaviors among employees, the practice of dangerous sports, consumer misbehavior, and pro-environmental behavior (Cheng, Li, Zhai, \& Smyth, 2014; Uba \& Chatzidakis, 2016). For example, Uba and Chatzidakis (2016) demonstrated the neutralization and affirmation techniques that university students employed to negotiate the cognitive dissonance of opposing or conflicting norms in the car-use context. Cheng et al. (2014) defined neutralization techniques as "rationalizations which individuals invoke to convince themselves, and others, that their deviant behaviors are justifiable and/or excusable" (p. 221). Previous research has demonstrated the five neutralization techniques proposed by Sykes and Matza (1957) in different contexts. These five techniques are: denial of responsibility, denial of injury, denial of victim, condemnation of condemners, and appeal to higher loyalties. Uba and Chatzidakis (2016) extended the range of neutralization techniques by adding five additional techniques: claim of normalcy, defense of necessity, claim of relative acceptability, claim of entitlement, and the change-locus-ofcontrol argument. 
Zhang, H., Huang, R., Zhang, Y., Buhalis, D., 2020, Cultural ecosystem services evaluation using geolocated social media data: a review, Tourism Geographies https://doi.org/10.1080/14616688.2020.1801828

In the car-based trip context, tourists may face the social-pressure dilemma of conforming to pro-driving and pro-environmental norms simultaneously. These two types of norms drive two opposing behaviors-namely, persist in or desist from car use-leading to a behavioral dilemma. Here, neutralization techniques likely become important strategies for reducing cognitive dissonance and feelings of guilt among tourists who persist in car use. Based on Uba and Chatzidakis (2016) and Cheng et al. (2014), the present study proposes seven techniques that car-based tourists may use to justify their persistence in car use: denial of responsibility, denial of injury, denial of victim, condemnation of condemners, appeal to higher loyalties, claims of normalcy, and the change-locus-ofcontrol argument. Denial of responsibility entails tourists persisting in car use by placing the blame on an alternative source or circumstance beyond their control, such as lack of public transportation (Siponen \& Vance, 2010; Uba and Chatzidakis, 2016). Denial of injury involves justifying car use by claiming that the environmental damage caused by car-based trips is insignificant, minimal, or even harmless (Cheng et al., 2014; Uba \& Chatzidakis, 2016). Denial of victim claims that the victim (e.g., tourism destination) deserves whatever happens as a consequence of developing car-based tourism. Condemnation of condemners occurs when tourists persisting in car use criticize those who condemn them in an effort to shift the blame. Appeal to higher loyalties seeks to justify car-use behavior as being for the greater good or for more important benefits. Claims of normalcy justify taking car-based trips as a lifestyle choice, arguing that the car is the main travel mode for most tourists. The change-locus-of-control argument claims that a single individual's desistance from taking car-based trips does not make a difference (Uba \& Chatzidakis, 2016). Following Cheng et al. (2014), this study conceptualized neutralization techniques as a formative second-order construct with reflective first-order subconstructs (i.e., seven dimensions). Car-based tourists who employ these techniques to rationalize their car-use behavior may strengthen the intention to persist in car use. Therefore, the following hypothesis is formulated:

H8: Tourists' use of neutralization techniques positively influences their intention to take car-based trips. Figure 1 shows the conceptual model and hypotheses.

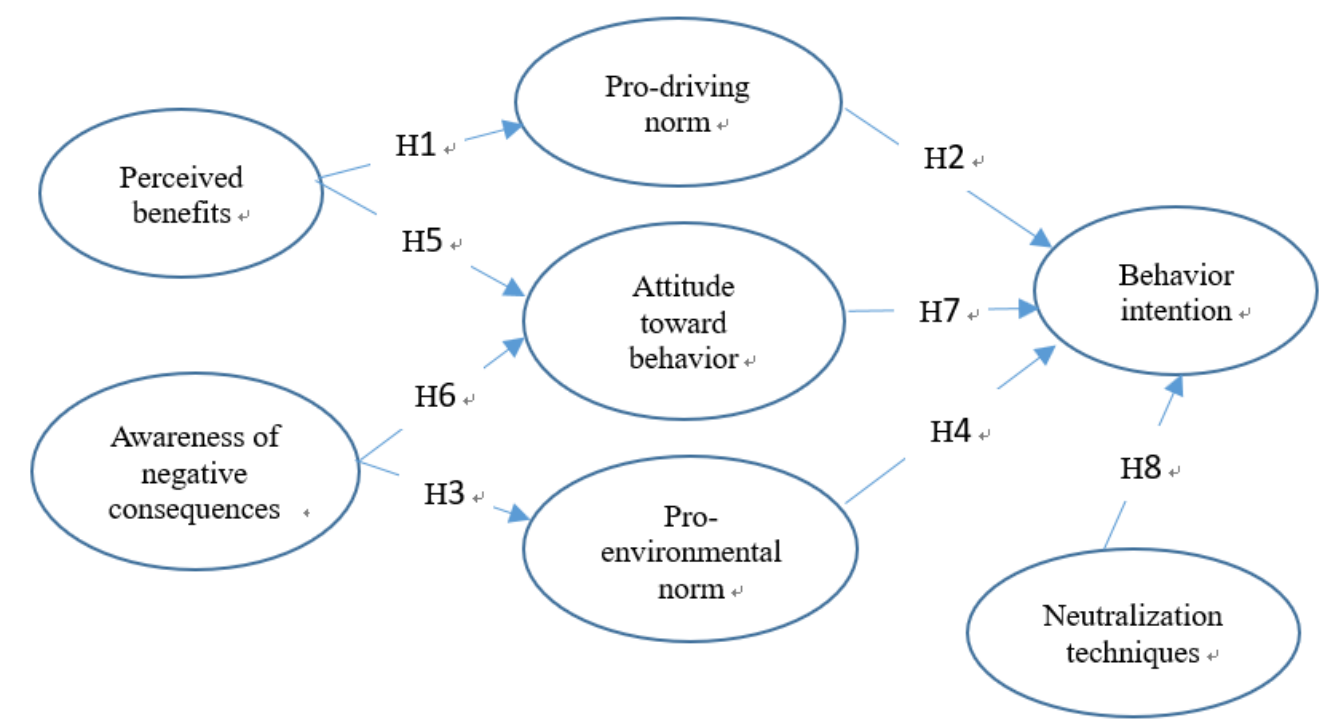


Zhang, H., Huang, R., Zhang, Y., Buhalis, D., 2020, Cultural ecosystem services evaluation using geolocated social media data: a review, Tourism Geographies https://doi.org/10.1080/14616688.2020.1801828

\section{Methodology}

\subsection{Measurement instruments}

Given the lack of scales in research on car-based trips, the measurement scales used in this study were developed from previous related qualitative and quantitative studies. The perceived benefits scale was developed based on Ellaway et al. (2003) and Uba and Chatzidakis (2016). Ellaway et al. (2003) investigated the psychosocial benefits of private motor vehicle use in daily life. Uba and Chatzidakis (2016) reviewed a wide range of benefits from previous studies regarding car-use behavior. Based on these benefits, the present study developed a six-item scale to measure tourists' perceived benefits from car use, including convenience, comfort, mastery, autonomy, prestige, and pleasure. The scale for the AC of car-based trips was developed from Gao et al. (2016); Kiatkawsin and Han (2017); Luo, Beckon, and Zhong (2018); and Lin (2010). Those studies measured either tourists' perceptions of the negative effects of tourism development and the tourism industry in general or carbon dioxide emissions from transport in destinations. This study, meanwhile, modified those studies' scales into a six-item scale to measure tourists' perceptions of the negative effects of car-based trips, including air pollution, energy use, crowding, noise, animal and plant disturbance, and natural resource damage.

Attitudes toward car-based trips were measured by a scale adapted from Goh et al. (2017) and included four items (desirable, good, wise, and favorable). This study viewed pro-driving norms as descriptive norms; the measurement scale was developed mainly from Uba and Chatzidakis (2016), Whitmarsh and O'Neill (2010), and Goh et al. (2017) and included three items. The pro-environmental norms scale was adapted from Gao et al. (2016) and Kiatkawsin and Han (2017), and it included four items to measure respondents' perceptions of tourists' responsibility for environmental protection. The neutralization techniques scale was developed from Uba and Chatzidakis (2016) and Cheng et al. (2014); it included seven dimensions and 21 items. The intention to take carbased trips was measured by a scale adapted from Cheng et al. (2014) and it was composed of three items. All of the items were measured on a five-point Likert scale ( $1=$ strongly disagree to $5=$ strongly agree). A pretest with 100 questionnaires was conducted at a pilot national park (Wuyi Mountain) in Fujian Province, China. After minor adjustments to wording and formatting, the final version of the questionnaire was developed.

\subsection{Data collection}

Data were collected at the Headwaters of Qianjiang River (QJY) National Park-a pilot national park in Zhejiang Province, China-during the 2017 Super Golden Week (an eight-day holiday from October 1 to October 8). Compared to the Wuyi Mountain National Park, the QJY national park is less famous and less accessible. The private car is the major transport mode for tourists to access this national park. QJY occupies an area of $252 \mathrm{~km}^{2}$, composed of the Gutianshan National Nature Reserve $\left(81.07 \mathrm{~km}^{2}\right)$, QJY National Forest Park $\left(45 \mathrm{~km}^{2}\right)$, and the ecological corridor connecting those two areas (Figure 2). The primary goal of the QJY National Park is to protect the ecological service functions of the original area of Qianjiang River and the evergreen broadleaf forest ecosystem in East China's mid-subtropical region.

A total of 550 self-administered questionnaires were disseminated, and 545 were returned. Following Hair, Black, Babin, and Anderson (2010), cases with more than $10 \%$ of the data missing were eliminated. In addition, questionnaires with more than 10 consecutive identical answers were also excluded. After removing the invalid questionnaires, 449 valid ones were further analyzed, for a valid percentage of $82.4 \%$. Table 2 shows the sociodemographic profiles and behavior characteristics of the respondents. There were more male respondents than female respondents ( $56.1 \%$ male vs. $43.9 \%$ female). Most respondents (71.4\%) were aged $18-45,18.3 \%$ were $45-60$, and $13.6 \%$ were under 18 . Regarding education, $40.8 \%$ of respondents had a bachelor's degree, and $26.1 \%$ had a diploma. The majority of the respondents were from Zhejiang Province (79.7\%) and had organized their trips by themselves (98.9\%). Almost half of the sample had traveled three times or more in the past six months (45.3\%). 
Zhang, H., Huang, R., Zhang, Y., Buhalis, D., 2020, Cultural ecosystem services evaluation using geolocated social media data: a review, Tourism Geographies https://doi.org/10.1080/14616688.2020.1801828

\begin{tabular}{lll}
\hline Table 2. Sample characteristics $(\mathrm{N}=449)$ \\
\hline Variables & Levels & Valid percentage (\%) \\
\hline Gender & Male & 56.1 \\
\multirow{2}{*}{ Age } & Female & 43.9 \\
& Under 18 & 13.6 \\
& $18-30$ & 32.9 \\
& $30-45$ & 38.5 \\
Education & H5-60 & 18.3 \\
& Above 60 & 1.1 \\
& Diph school or lower & 25.6 \\
& Bachelor's degree & 26.1 \\
Region & Master's or higher & 70.8 \\
& Zhejiang Province & $79.7 \%$ \\
Travel pattern & Independent travel & $19.3 \%$ \\
& Other provinces & 98.9 \\
months & Group tour & 1.1 \\
\hline
\end{tabular}

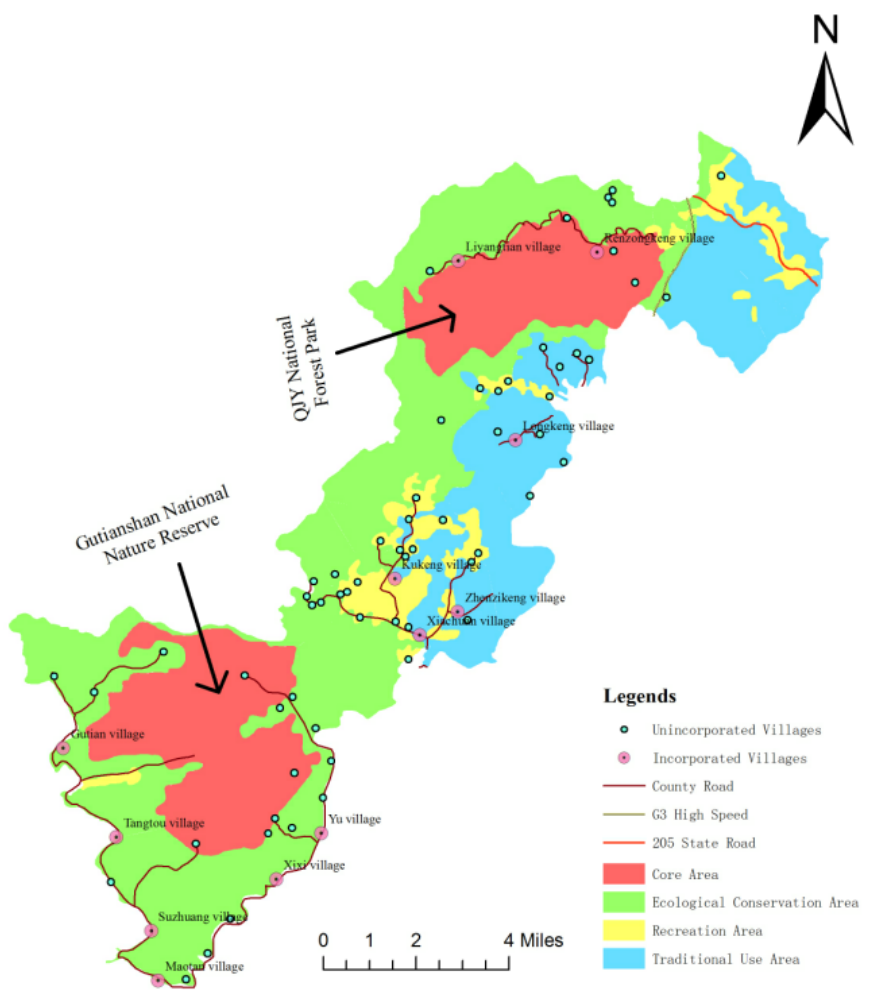


Zhang, H., Huang, R., Zhang, Y., Buhalis, D., 2020, Cultural ecosystem services evaluation using geolocated social media data: a review, Tourism Geographies https://doi.org/10.1080/14616688.2020.1801828

\subsection{Data analysis}

Using SmartPLS 3.0, partial least squares structural equation modeling (PLS-SEM) was employed to evaluate the psychometric properties of the measurement scales and to test the hypotheses. According to Hair, Hult, Ringle, and Sarstedt (2014), PLS-SEM can be used when: (1) the research goal is to identify key driver constructs rather than theory testing, confirmation, or comparison; (2) formative measures are included in the structural model; (3) the structural model is complex with many constructs and indicators; (4) the sample size is small; and (5) the data are non-normally distributed. In this study, the goal was to identify the key driving constructs of the intention to take a car-based trip in a conflicting-norm context. The construct for neutralization techniques was conceptualized as a second-order formative construct with first-order reflective indicators. The model was complex with 14 latent constructs and 47 indicators, and the data distributions of 17 indicators were non-normal, because their skewness and/or kurtosis were beyond the range of -1 to +1 (Hair et al., 2014; Zhang, Wu, \& Buhalis, in press) (Table 3). Therefore, for this study, variance-based PLS-SEM was preferable to covariance-based SEM using AMOS or LISREL. The bootstrapping technique was used to test significance with 449 cases, 1,000 subsamples, and no sign changes (Hair et al., 2014; Wells, Taheri, Gregory-Smith, \& Manika, 2016; Zhang et al., 2018).

Before PLS-SEM was conducted, SPSS was used to calculate the descriptive statistics, treat missing values, and test for common method bias. According to Hair et al. (2014), the normality of distributions can be evaluated by skewness and kurtosis. If the skewness or kurtosis of a distribution is greater than +1 or lower than -1 , the assumption of normality is violated. Table 3 shows that the distributions of 17 indicators were non-normal. The amount of missing data was very small, with $1 \%$ as the maximum rate (less than $5 \%$ per indicator); therefore, all of the missing data were replaced by EM (expectation-maximization algorithm) (Hair et al., 2014; Zhang et al., in press). Common method bias was tested using Harmon's one-factor test approach (Chiu, Lee, \& Chen, 2014; Zhang et al., in press). Exploratory factor analysis was conducted for all of the indicators. The results showed 11 factors with Eigenvalues greater than 1, explaining $68.37 \%$ of the total variance. The first factor accounted for only $20.52 \%$ of the total variance (less than $50 \%$ ), indicating that the results were not biased by common method variance.

\section{Results}

\subsection{Measurement model}

Different from covariance-based SEM, PLS-SEM does not provide a single goodness-of-fit criterion to evaluate the measure model and structural model; rather, it provides a set of nonparametric evaluation criteria. Following the recommendation of Hair et al. (2014), there are two types of measurement models: a reflective measurement model and a formative measurement model. The evaluation criteria for the reflective measurement model include composite reliability, indicator reliability, convergent validity (average variance extracted), and discriminant validity. The evaluation criteria for the formative measurement model include convergent validity, collinearity among indicators, and significance and relevance of outer weights. In this study, all of the first-order constructs were reflectively measured (Table 3). The reliability and the convergent and discriminate validity of the 14 first-order reflective constructs were assessed. Seven indicator loadings were lower than the recommended threshold of 0.7. After removing those seven indicators, all of the outer loadings were above 0.7 , the composite reliabilities (CR) ranged from 0.842-0.934 (above the 0.7 threshold value), and the average variances extracted (AVEs) ranged from 0.640-0.825 (above the 0.5 threshold value), indicating the internal consistency and convergent validity of the measurement models. Following Fornell and Larcker's (1981) criterion that the square root of the AVE of a construct should be larger than the biggest correlation between that construct and any other construct, the discriminate validity of the 13 first-order reflective constructs (one construct was removed in the above assessment process) was assessed and confirmed. 
Zhang, H., Huang, R., Zhang, Y., Buhalis, D., 2020, Cultural ecosystem services evaluation using geolocated social media data: a review, Tourism Geographies https://doi.org/10.1080/14616688.2020.1801828

Table 3. Assessment of the first-order measurement model and descriptive statistics

\begin{tabular}{|c|c|c|c|c|c|c|c|}
\hline Items & Mean & Skewness & Kurtosis & Loading & t-value & $\mathbf{C R}$ & AVE \\
\hline Perceived benefits & & & & & & \multirow{7}{*}{0.856} & \multirow{7}{*}{0.664} \\
\hline Car-based trips are convenient & 4.17 & -1.014 & 2.250 & 0.814 & 29.894 & & \\
\hline Car-based trips make me feel comfortable & 4.13 & -.769 & 1.049 & 0.850 & 47.967 & & \\
\hline Car-based trips make me feel autonomous and flexible* & 4.34 & -1.057 & 2.525 & - & - & & \\
\hline Car-based trips make me feel in control & 4.01 & -.885 & .865 & 0.780 & 28.531 & & \\
\hline Car-based trips make me feel prestige* & 2.99 & .162 & -.655 & - & - & & \\
\hline Car-based trips give me driving pleasure* & 3.84 & -.620 & .056 & - & - & & \\
\hline Awareness of negative consequences & & & & & & \multirow{7}{*}{0.916} & \multirow{7}{*}{0.646} \\
\hline Private cars can increase carbon emissions and air pollution & 3.57 & -.345 & -.130 & 0.840 & 8.089 & & \\
\hline Private cars consume more energy & 3.58 & -.330 & -.113 & 0.870 & 8.879 & & \\
\hline Car-based trips lead to congestion in destinations & 3.68 & -.498 & .267 & 0.737 & 7.721 & & \\
\hline Car crowding damages roadside natural resources & 3.25 & -.005 & -.550 & 0.825 & 8.876 & & \\
\hline Private cars increase noise pollution in destinations & 3.34 & -.135 & -.421 & 0.827 & 8.817 & & \\
\hline Private cars disturb animals and plants in destinations & 3.21 & -.090 & -.535 & 0.709 & 7.215 & & \\
\hline Pro-driving norms & & & & & & \multirow{4}{*}{0.883} & \multirow{4}{*}{0.716} \\
\hline The private car has become a popular travel mode & 3.82 & -.496 & .494 & 0.825 & 32.353 & & \\
\hline My family and friends support car-based trips & 3.73 & -.454 & .608 & 0.908 & 93.405 & & \\
\hline Tourist destinations encourage and advocate car-based trips & 3.43 & -.080 & -.053 & 0.803 & 25.298 & & \\
\hline Pro-environmental norms & & & & & & \multirow{5}{*}{0.929} & \multirow{5}{*}{0.814} \\
\hline Tourists have a responsibility to protect the environment & 4.56 & -1.546 & 4.334 & 0.924 & 61.557 & & \\
\hline $\begin{array}{l}\text { Tourists have a responsibility to minimize the negative effects } \\
\text { on resources and environment }\end{array}$ & 4.51 & -1.624 & 3.698 & 0.914 & 49.933 & & \\
\hline $\begin{array}{l}\text { Tourists should take responsibility for environmental } \\
\text { degradation in destinations* }\end{array}$ & 3.93 & -.782 & -.145 & - & - & & \\
\hline $\begin{array}{l}\text { Tourists have a responsibility to choose environmentally } \\
\text { friendly behaviors }\end{array}$ & 4.46 & -1.255 & 2.823 & 0.867 & 33.111 & & \\
\hline Attitudes toward car-based trips & & & & & & \multirow{5}{*}{0.912} & \multirow{5}{*}{0.723} \\
\hline Car-based trips are desirable & 3.90 & -.436 & -.080 & 0.830 & 46.933 & & \\
\hline Car-based trips are a good travel mode & 4.04 & -.297 & -.551 & 0.873 & 65.658 & & \\
\hline Taking a car-based trip is wise & 3.82 & -.077 & -.827 & 0.867 & 52.685 & & \\
\hline Car-based trips are favorable & 4.00 & -.191 & -.677 & 0.830 & 46.618 & & \\
\hline Denial of responsibility & & & & & & \multirow{4}{*}{0.926} & \multirow{4}{*}{0.807} \\
\hline $\begin{array}{l}\text { Must choose car-based trip because the destination lacks } \\
\text { public transport facilities }\end{array}$ & 3.42 & -.396 & -.186 & 0.883 & 48.721 & & \\
\hline $\begin{array}{l}\text { Must choose car-based trip because of bad public transport } \\
\text { services }\end{array}$ & 3.34 & -.181 & -.415 & 0.915 & 61.171 & & \\
\hline $\begin{array}{l}\text { Must choose car-based trip because of a lack of public } \\
\text { transport service information }\end{array}$ & 3.37 & -.314 & -.260 & 0.897 & 73.788 & & \\
\hline Denial of injury & & & & & & \multirow[t]{4}{*}{0.888} & \multirow[t]{4}{*}{0.727} \\
\hline Car-based trips do not damage the environment & 2.95 & .204 & -.304 & 0.858 & 57.620 & & \\
\hline The environmental damage from car-based trips is very small & 3.04 & .038 & .007 & 0.890 & 55.048 & & \\
\hline The environmental damage from car-based trips is negligible & 2.89 & .092 & -.290 & 0.807 & 24.802 & & \\
\hline Denial of victim & & & & & & \multirow[t]{4}{*}{-} & \multirow[t]{4}{*}{-} \\
\hline $\begin{array}{l}\text { If they are worried about environmental damage, destinations } \\
\text { should have better car-based-trip management* }\end{array}$ & 4.11 & -.864 & 1.006 & - & - & & \\
\hline $\begin{array}{l}\text { I do not really believe car-based trips cause much } \\
\text { environmental damage in destinations* }\end{array}$ & 3.15 & -.157 & -.393 & - & - & & \\
\hline $\begin{array}{l}\text { If destinations overdevelop the tourism industry, } \\
\text { environmental damage is inevitable* }\end{array}$ & 3.57 & -.515 & -.097 & - & - & & \\
\hline Condemnation of condemners & & & & & & \multirow[t]{4}{*}{0.934} & \multirow[t]{4}{*}{0.825} \\
\hline Destinations should improve public transport infrastructure & 4.11 & -.802 & 1.251 & 0.905 & 59.612 & & \\
\hline $\begin{array}{l}\text { Destinations should do their best to improve public transport } \\
\text { service }\end{array}$ & 4.12 & -1.030 & 1.974 & 0.934 & 73.595 & & \\
\hline $\begin{array}{l}\text { Destinations should worry more about other environmental } \\
\text { damage behaviors }\end{array}$ & 4.09 & -.830 & 1.190 & 0.886 & 50.088 & & \\
\hline Appeal to higher loyalties & & & & & & \multirow{4}{*}{0.914} & 0.780 \\
\hline My family likes taking car-based trips together & 3.88 & -.871 & 1.769 & 0.896 & 56.864 & & 0.180 \\
\hline My friends like taking car-based trips together & 3.89 & -.540 & 1.165 & 0.922 & 82.897 & & \\
\hline Car-based trips can enhance affection and friendship & 3.98 & -.824 & 1.416 & 0.829 & 34.901 & & \\
\hline Claims of normalcy & & & & & & 0.881 & 0.712 \\
\hline Car-based trips have become a lifestyle & 3.74 & -.479 & .749 & 0.792 & 30.038 & & \\
\hline Car-based trips have become the main travel mode & 3.64 & -.185 & -.277 & 0.895 & 76.940 & & \\
\hline
\end{tabular}


Zhang, H., Huang, R., Zhang, Y., Buhalis, D., 2020, Cultural ecosystem services evaluation using geolocated social media data: a review, Tourism Geographies https://doi.org/10.1080/14616688.2020.1801828

\begin{tabular}{|c|c|c|c|c|c|c|c|}
\hline The majority of tourists choose car-based trips & 3.51 & -.145 & -.195 & 0.841 & 45.815 & \multirow{4}{*}{0.842} & \multirow{2}{*}{0.640} \\
\hline Change-locus-of-control argument & & & & & & & \\
\hline Others still choose car-based trips, even if I do not do so & 3.27 & -.222 & .084 & 0.760 & 20.836 & & \\
\hline $\begin{array}{l}\text { It will not make a difference if I alone choose not to take car- } \\
\text { based trips }\end{array}$ & 3.08 & -.131 & .371 & 0.823 & 30.430 & & \\
\hline $\begin{array}{l}\text { It is difficult to make a difference when I alone choose not to } \\
\text { take car-based trips }\end{array}$ & 3.17 & -.072 & -.094 & 0.814 & 36.648 & & \\
\hline Intention to take car-based trips & & & & & & 0.897 & 0.746 \\
\hline I intend to take car-based trips & 3.79 & -.134 & -.171 & 0.914 & 94.148 & & \\
\hline I plan to take a car-based trip next time & 3.74 & -.058 & -.417 & 0.898 & 61.265 & & \\
\hline I will take a car for short trips & 4.06 & -.495 & 1.098 & 0.772 & 28.953 & & \\
\hline
\end{tabular}

$355 *$ Items deleted in the measurement model test.

356

357

358

359

360

361

362

363

364

365

366

367

368

369

370

\section{1}

372

373

374

375

376

377

378

379

380

381

382

383

Neutralization techniques were conceptualized as a second-order formative construct. The criteria of content validity, collinearity, and the significance and relevance of the first-order constructs were used to assess measurement quality. Establishing content validity requires that the first-order constructs capture all or at least the major facets of the second-order construct; a thorough literature review and expert assessment can help to ensure content validity (Hair et al., 2014). Based on a review of the literature on neutralization theory, five major domains were included. In addition, this study added two more domains based on a qualitative exploration of car use among university students. Three experts in the field assessed the facets and ambiguities, and verified content validity. The variance inflation factor (VIF) was used to assess the level of collinearity. All of the VIFs ranged from 1.1461.504 (below the recommended value of 5), indicating no potential collinearity problem. The significance of the first-order constructs to the second-order construct was assessed by path coefficients (Zhang et al., in press). All of the path coefficients were significant at the 0.001 level (Table 4), indicating the significant contribution of the six first-order constructs to the second-order construct.

Table 4. Assessment of the second-order measurement model

\begin{tabular}{llll}
\hline Second-order construct & First-order constructs & Path coefficient & t-value \\
\hline Neutralization techniques & Denial of responsibility & 0.191 & 5.731 \\
& Denial of injury & 0.245 & 10.458 \\
& Condemnation of the condemners & 0.270 & 9.817 \\
& Appeal to higher loyalties & 0.347 & 14.943 \\
& Claim of normalcy & 0.308 & 14.788 \\
& Change-locus-of-control argument & 0.209 & 9.208 \\
\hline
\end{tabular}

\subsection{Structural model}

Figure 3 shows the results of the structural model analysis for the proposed model. The model explained $37.2 \%$ of the total variance in national park tourists' intentions to take car-based trips. Attitude toward the behavior was the most important factor affecting tourists' behavior intentions, with a path coefficient of $0.34(t=5.429, p=$ 0.000). The second most important factor was neutralization techniques, with a path coefficient of $0.27(t=4.899$, $p=0.000$ ). The third factor significantly affecting tourists' behavior intentions was pro-driving norms, with a path coefficient of $0.14(t=2.074, p=0.038)$. Pro-environmental norms had no significant effect on tourists' behavior intentions, with a 0.004 path coefficient $(t=0.077, p=0.939)$. The perceived benefits of car-based trips had a significant effect on pro-driving norms $(B=0.34, \mathrm{t}=7.188, \mathrm{p}=0.000)$ and attitudes toward behaviors $(B=0.59, \mathrm{t}=$ 18.469, $p=0.000)$. The $A C$ of car-based trips had a significant effect on pro-environmental norms $(B=0.14, t=$ 2.880, $p=0.004)$ but no significant effect on attitudes toward the behavior $(b=-0.04, t=0.892, p=0.373)$. Therefore, except for $\mathrm{H} 4$ and $\mathrm{H} 6$, all of the other hypotheses ( $\mathrm{H} 1, \mathrm{H} 2, \mathrm{H} 3, \mathrm{H} 5, \mathrm{H} 7$, and $\mathrm{H} 8$ ) were supported by the data. 
Zhang, H., Huang, R., Zhang, Y., Buhalis, D., 2020, Cultural ecosystem services evaluation using geolocated social media data: a review, Tourism Geographies https://doi.org/10.1080/14616688.2020.1801828

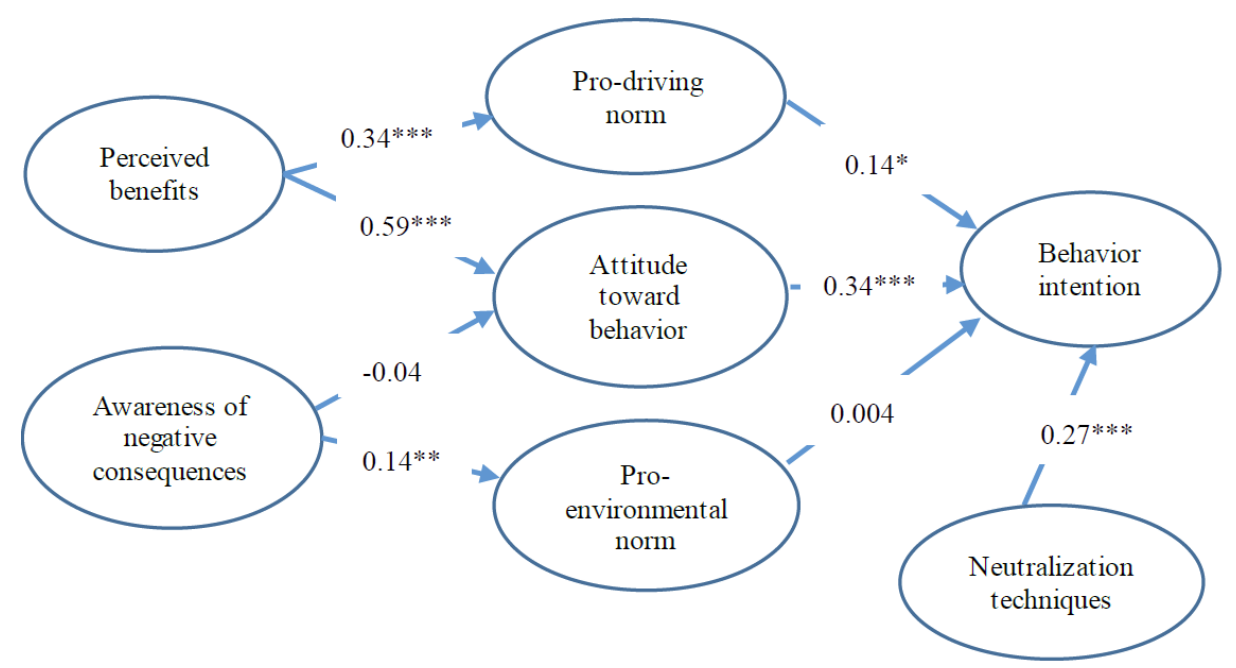

Figure 3. Results of PLS analysis for the research model

To examine and compare the role of neutralization techniques in forming behavior intentions, an alternative model (Figure 4) was tested that removed neutralization techniques from the original proposed model. The alternative model explained $32.3 \%$ of the total variance in national park tourists' intentions to take car-based trips. This is lower than the original model (37.2\%), indicating that the original model had a larger predictive power for national park tourists' intentions to take car-based trips. Pro-driving norms had more significant effects on behavior intentions in the alternative model $(B=0.26, t=4.203, p=0.000)$ than in the original $(\theta=0.14, t=2.074, p=0.038)$. The $B$ value between attitudes and behavior intentions increased from $0.34(t=5.429, p=0.000)$ to $0.39(t=6.989$, $p=0.000$ ), indicating that attitude was the most important and stable influencing factor. The 6 value between proenvironmental norms and behavior intention increased, too, from 0.004 to 0.013 , but still was not significant. In both structural models, perceived benefits explained $11.3 \%$ and $35.0 \%$ of the variance in pro-driving norms and attitudes, respectively; only $1.6 \%$ of the variance in pro-environmental norms was explained by the awareness of negative consequences.

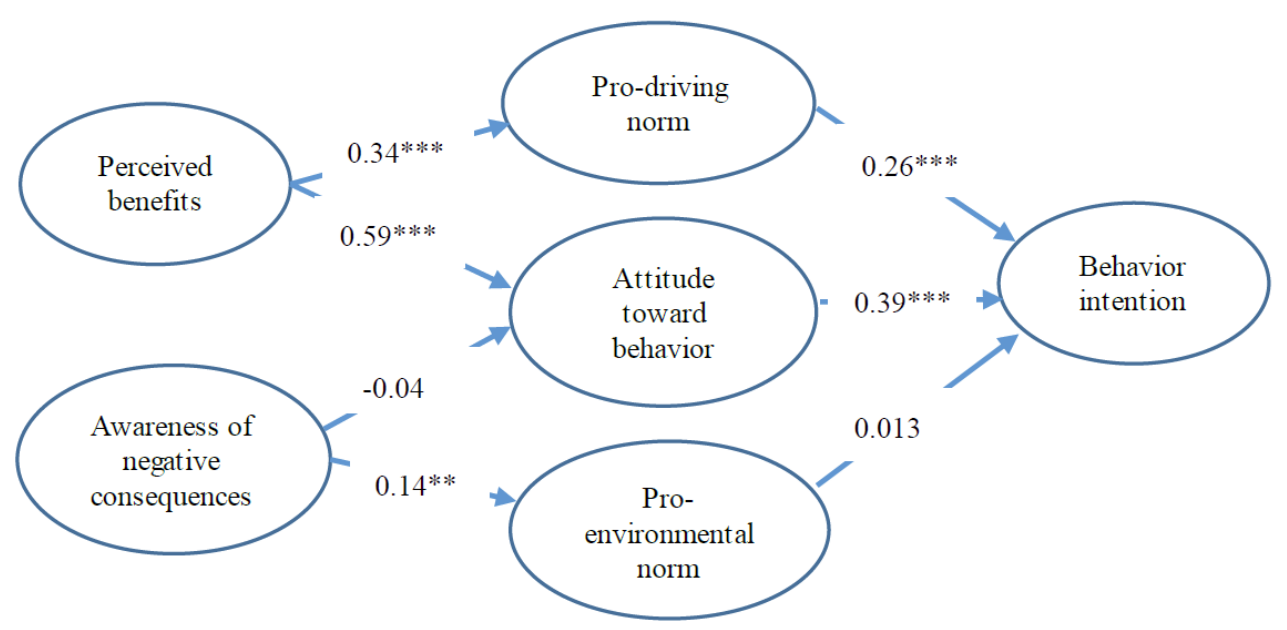

Figure 4. Results of PLS analysis for the alternative model 
Zhang, H., Huang, R., Zhang, Y., Buhalis, D., 2020, Cultural ecosystem services evaluation using geolocated social media data: a review, Tourism Geographies https://doi.org/10.1080/14616688.2020.1801828

404

405

406

407

408

409

410

411

412

413

414

415

416

417

418

419

420

421

422

423

424

425

426

427

428

429

430

431

432

433

434

435

436

437

438

439

440

441

442

443

444

445

446

\section{Discussion}

By integrating the theory of planned behavior, the norm-activation model, and neutralization theory, this study developed a norm-neutralization model to predict national park tourists' intentions to take car-based trips in a conflicting-norm context. The proposed theoretical model included: (1) four determinants of car-based-trip intention (pro-driving norms, pro-environmental norms, attitudes toward the behavior, and neutralization techniques) and (2) two antecedents of those determinants (perceived benefits and awareness of negative consequences). The model explained $37.2 \%$ of the variance in the intention to take car-based trips, indicating that the norm-neutralization model is appropriate for car-based-trip research. These findings contribute to the understanding of pro-environmental behaviors by showing the formation processes and determinants of tourists' intentions to take car-based trips.

This study integrated two opposite norms (pro-driving and pro-environmental norms) into one model to explain national park tourists' intentions to take car-based trips. The results indicated that pro-driving norms have a significant positive effect on behavior intentions while pro-environmental norms have no effect. When the NAM (awareness of negative consequences $\rightarrow$ pro-environmental norms $\rightarrow$ behavior intention) was run independently, pro-environmental norms exhibited a significant positive effect on behavior intentions $(B=0.20, t=5.528, p=$ 0.000); however, the relationship direction was unexpected. The most likely reason for this is that national park tourists who hold higher levels of internalized pro-environmental personal norms are also driving enthusiasts. They are more highly aware of environmental problems as a result of their rich tourist experiences by car, which give them more chances to sense the negative effects of car travel. As such, the positive relationship between proenvironmental norms and behavior intentions may be a spurious correlation due to a third variable.

After integrating NAM with TPB, the effect of pro-environmental norms became nonsignificant. This is congruent with Donald et al. (2014) and Nilsson and Kuller (2000). TPB and NAM are two important theories for explaining pro-environmental intentions or behaviors. Previous studies have discussed and tested the appropriateness of these two theories. Generally speaking, NAM usually explains pro-environmental intentions or behaviors activated by pro-social motives, while TPB is often used to explain intentions or behaviors involving selfinterest motives (Bamberg et al., 2007; Chen \& Tung, 2014; Kim, Njite, et al., 2013; Zhang, Wang, \& Zhou, 2013). Some researchers combined the two models into integrated models and argued that the integrated models had more satisfactory levels of predictive power for pro-environmental intentions (Han, 2015). In the present study, social norms were conceptualized differently from previous integrated models. First, different from subjective norms, pro-driving norms were viewed as descriptive norms that measure tourists' perceptions of "normal" behaviors, or what most people do. Second, pro-environmental norms were viewed as different from the personal norms used other researchers. Most pro-environmental behavior research has defined personal norms as individuals' feelings of moral obligation to perform pro-environmental behaviors. Following Gao et al. (2016), this study measured pro-environmental norms via collective responsibility. Third, previous studies have directed different norms (e.g., subjective norms and personal norms) at the same object (e.g., staying at a green hotel) while this study directed social norms at different objects (i.e., driving vs. environment protection). These differences may account for results that diverge from those of previous research. When norms directed at different objects (especially conflicting objects) are integrated into one model, the predictive patterns of those norms may change. Another explanation for the nonsignificant effect of pro-environmental norms is that national park tourists' intentions to take car-based trips are mainly motivated by self-interest; therefore, rational-choice models are more appropriate.

Neutralization techniques were found to be an important factor influencing national park tourists' intentions 
Zhang, H., Huang, R., Zhang, Y., Buhalis, D., 2020, Cultural ecosystem services evaluation using geolocated social media data: a review, Tourism Geographies https://doi.org/10.1080/14616688.2020.1801828

to take car-based trips. When neutralization techniques were integrated into the model, the effect sizes of other antecedents decreased. National park tourists may face pressures from different, even opposing, social norms. In particular, pro-driving norms encourage tourists to take car-based trips, but pro-environmental norms discourage this behavior. Such inconsistencies in norm requirements often produce cognitive dissonance for tourists. According to Festinger (1957), cognitive dissonance occurs when a person simultaneously holds two or more contradictory beliefs, ideas, or values. Some strategies can be used to reduce internal inconsistency and psychological discomfort, such as changing cognition, adding new information, or avoiding contradictory information. Neutralization techniques are strategies for changing cognition; they can help individuals justify or rationalize their norm-violating behaviors to maintain a positive self-concept or self-identity. This study's results are consistent with Cheng et al. (2014), who found that neutralization was the strongest predictor of the intention to use organization-provided Internet for personal purposes. The results are also consistent with Uba and Chatzidakis's (2016) qualitative research, which found that university students employed various neutralization techniques to justify their car-use behaviors. Compared to the model without neutralization techniques (Figure 3), the norm-neutralization model (Figure 2) had higher predictive power for tourists' intentions to take car-based trips. This means that neutralization techniques are efficient strategies for dealing with social pressure dilemmas in conflicting-norm contexts. By reducing the effects of conflicting social norms, neutralization techniques decrease levels of inconsistency and discomfort, thus maintaining a positive self-image or sense of self for tourists.

Among all of the antecedents, attitudes toward behavior were the strongest predictors of national park tourists' intentions to take car-based trips. This is consistent with some studies (e.g., Kim \& Han, 2010; Untaru, Ispas, Candrea, Luca, \& Epuran, 2016) but inconsistent with others (e.g., Kim, Njite et al., 2013). There could be a range of reasons for this, such as model development, research context, focus behavior, and so on. Perceived benefits and awareness of negative consequences of car-based trips are the positive and negative beliefs tourists hold about car-based trips. Consistent with previous TPB-based studies (e.g., Bamberg \& Schmidt, 2003; Kim, E. et al., 2013), the results showed that positive beliefs contributed to the formation of pro-driving norms and positive attitudes. Negative beliefs activated tourists' pro-environmental norms, which is inconsistent with Gao et al. (2016). Most NAM-based research has not investigated the direct effects of the awareness of negative consequences on personal norms. Gao et al. (2016) examined this direct effect but found it nonsignificant. However, in an integrated model of TPB and NAM developed by Zhang et al. (2017), awareness of consequences indirectly affected environmental complaint intention via personal norms, attitudes, and subjective norms. Namely, awareness of consequences had a significant direct effect on personal norms in that study. This is consistent with the findings of the present study.

\section{Conclusion}

TPB, NAM, and their extended or integrated models have been widely used to explain a range of tourists' proenvironmental behaviors. Both subjective and personal norms have been shown to be important determinants of pro-environmental behaviors. Few studies, however, have investigated the effects of two conflicting types of norms in one model. Neutralization theory has been widely used in research on norm-violating behaviors, but it is rarely used in pro-environmental behavior research. The car-based trip is also a less studied pro-environmental behavior. Therefore, this study contributes to pro-environmental behavior literature by integrating TPB, NAM, and neutralization theory, and especially by including conflicting norms and neutralization techniques in the proposed model (i.e., the norm-neutralization model). This new perspective can broaden the range of theory integration in pro-environmental behavior research and enhance our understanding of pro-environmental behaviors.

As an important category of protected areas, national parks have the dual goals of ecological protection and recreation. Transportation is a major challenge for environmental management in national parks. Although public 
Zhang, H., Huang, R., Zhang, Y., Buhalis, D., 2020, Cultural ecosystem services evaluation using geolocated social media data: a review, Tourism Geographies https://doi.org/10.1080/14616688.2020.1801828

transit systems operate in many national parks, tourists still prefer driving. This study's results can help park managers to understand why national park tourists persist in taking car-based trips and adopt appropriate management strategies. First, pro-driving norms are important determinants influencing car-based-trip intentions; the perceived benefits of car-based trips activate the formation of pro-driving norms. Several methods can be used to reduce the social stress of pro-driving norms: (1) providing alternative public transportation systems, gateway communities, and greater perceived benefits (e.g., convenience, comfort, and cost); (2) encouraging tourists to use public transportation and cultivating the habit through a reward system (e.g., reduce or relieve ticket costs); and (3) restricting private car use by reducing its perceived benefits (e.g., charge higher parking fees and congestion taxes).

Visitors employ various neutralization techniques to justify their car-use behavior. Corresponding interventions can decrease the role of these neutralization techniques as follows: (1) Appeal to higher loyalties and claims of normalcy are the first two important neutralization techniques. Therefore, encouraging sustainable and green consumption and behavior patterns in the whole society may change visitors' evaluations of important others' expectations and social normalcy. (2) To avoid being blamed by visitors, national parks should increase public transportation facilities and service levels. ICTs can be used to provide timely and rich transportation information for tourists. (3) Provide environmental education information (including the damaging effects of car use) to tourists via various media throughout the whole travel process (pre-travel, on-site, and post-travel). (4) Cultivate the idea that environmental protection begins with the individual and that everyone is responsible for environmental protection.

This research has some limitations. First, as with most research, the generalizability of the findings can be debated. In this study, generalizability issues could arise in several ways: (1) The study area was a pilot national park in East China, which differs from the definition of national parks set by the International Union for the Conservation of Nature (IUCN), though reforms are being made to meet IUCN goals. (2) Each national park is different in its physical environment, infrastructure, public service system, tourism information, and other conditions. (3) The survey was conducted during China's Super Golden Week; this means there were large numbers of car-based tourists in most tourism areas, which could produce more salient environmental problems. (4) The sample was composed of tourists from a developing country, where private car ownership may still be considered a symbol of prestige and status. (5) Each visitor is different in terms of consumption and time budgets, and visitors' behavior intentions may be different under different ambient pressures. Therefore, the proposed norm-neutralization model should be confirmed in a different country, a different time period, and different kinds of national parks at different stages of development. Second, this study used a scale to measure pro-environmental norms that might be better suited to Chinese tourists by considering China's collective cultural characteristics; however, it did not find a significant effect on behavior intention. There could be two reasons for this: measurement issues and no expected relationship between pro-environmental norms and car-based-trip intentions. Future research can adopt the common scale used in most NAM-based research to examine the effect on behavior intention. Third, the neutralization techniques scale used in this study was developed from studies conducted in typical environments. However, it is possible that some special contextual factors exist (e.g., incomplete information, lack of public transport, insecurity, time deficiency, and placelessness) that could become neutralization techniques for tourists in unusual environments. Future research should explore these special neutralization techniques. Lastly, this study focused on car-based trips. Future research should explore public-transport-based trips, which would enrich tourist transportation behavior research from another perspective. Sustainable cars (e.g., electric cars) and eco-driving behaviors may reduce negative environmental effects (Nègre \& Delhomme, 2017) and further influence tourists' beliefs and intentions regarding taking car-based trips. This, too, warrants an examination in future research. 
Zhang, H., Huang, R., Zhang, Y., Buhalis, D., 2020, Cultural ecosystem services evaluation using geolocated social media data: a review, Tourism Geographies https://doi.org/10.1080/14616688.2020.1801828

533

\section{References}

Ajzen, I. (1991). The theory of planned behavior. Organizational Behavior and Human Decision Processes, 50, 179211.

Armitage, C. J., Conner, M. (2001). Efficacy of the theory of planned behaviour: A meta-analytic review. The British Journal of Social Psychology/The British Psychological Society, 40, 471-499.

Bamberg, S., Fujii, S., Friman, M., \& Garling, T. (2011). Behaviour theory and soft transport policy measures. Transport Policy, 18 (1), 228-235.

Bamberg, S., Hunecke, M., \& Blobaum, A. (2007). Social context, personal norms and the use of public transportation: Two field studies. Journal of Environmental Psychology, 27(3), 190-203.

Bamberg, S., \& Schmidt, P. (2003). Incentives, morality, or habit? Predicting students'car use for university routes with the models of Ajzen, Schwartz, and Triandis. Environment and Behavior, 35, 264-283.

Becken, S., Simmons, D. G., Frampton, C. (2003). Energy use associated with different travel choices. Tourism Management, 24(3), 267-277.

Beunen, R., Regnerus, H. D., \& Jaarsma, C. F. (2008). Gateways as a means of visitor management in national parks and protected areas. Tourism Management, 29(1), 138-145.

Chen M. F., \& Tung, P. J. (2014). Developing an extended Theory of Planned Behavior model to predict consumers' intention to visit green hotels. International Journal of Hospitality Management, 36 (1), 221-230.

Cheng, L., Li, W., Zhai, Q., \& Smyth, R. (2014). Understanding personal use of the Internet at work: An integrated model of neutralization techniques and general deterrence theory. Computers in Human Behavior, 38, 220228.

China Tourism Academy. (2017). Big data report of car-based trip (cross-cities) in China during the holiday for National Day and Mid-Autumn Festival. http://www.ctaweb.org/html/2017-10/2017-10-13-9-9-68840.html.

Chiu, Y. T. H., Lee, W. I., \& Chen, T. H. (2014). Environmentally responsible behavior in ecotourism: Antecedents and implications. Tourism Management, 40, 321-329.

Connell, J., \& Page, S. J. (2008). Exploring the spatial patterns of car-based tourist travel in Loch Lomond and Trossachs National Park, Scotland. Tourism Management, 29(3): 561-580.

Copes, H., \& Williams, J. P. (2007). Techniques of affirmation: Deviant behaviour, moral commitment, and subcultural identity. Deviant Behavior, 28 (3), 247-272.

Davies, N. J., \& Weston, R. (2015). Reducing car-use for leisure: Can organised walking groups switch from car travel to bus and train walks? Journal of Transport Geography, 48, 23-29.

De Groot, J. I., \& Steg, L. (2009). Morality and prosocial behaviour: The role of awareness, responsibility, and norms in the Norm Activation Model. The Journal of social psychology, 149(4), 425-449.

Donald, I. J., Cooper, S. R., \& Conchie, S. M. (2014). An extended theory of planned behaviour model of the psychological factors affecting commuters' transport mode use. Journal of Environmental Psychology, 40: 39 48.

Ellaway, A., Macintyre, S., Hiscock, R., \& Kearns, A. (2003). In the driving seat: Psychosocial benefits from private motor vehicle transport compared to public transport. Transportation Research Part F: Traffic Psychology and Behaviour, 6 (3), 217-231.

Farrow, K., Grolleau, G., \& Ibanez, L. (2017). Social norms and pro-environmental behavior: A review of the evidence. Ecological Economics, 140, 1-13.

Festinger, L. (1957). A theory of cognitive dissonance. Stanford: Stanford University Press.

Filimonau, V., Dickinson, J., \& Robbins, D. (2014). The carbon impact of short-haul tourism: A case study of UK travel to Southern France using life cycle analysis. Journal of Cleaner Production, 64, 628-638. 
Zhang, H., Huang, R., Zhang, Y., Buhalis, D., 2020, Cultural ecosystem services evaluation using geolocated social media data: a review, Tourism Geographies https://doi.org/10.1080/14616688.2020.1801828

Fishbein, M., \& Ajzen, I. (1975). Belief, attitude, intention, and behavior: An introduction to theory and research. Reading, MA: Addison-Wesley.

Fornell, C., \& Larcker, D. F. (1981). Evaluating structural equation models with unobservable variables and measurement Error. Journal of Marketing Research, 18(1), 39-50.

Gao, J., Huang, J., \& Zhang C. Z. (2016). Tourists' perceptions of responsibility: An application of norm-activation theory. Journal of Sustainable Tourism, Published online: $08 \mathrm{Jul} 2016$

Gardner, B., \& Abraham, C. (2010). Going Green? Modelling the impact of environmental concerns and perceptions of transportation alternatives on decisions to drive. Journal of Applied Social Psychology, 40, 831-849.

Goh, E., Ritchie, B., Wang, J. (2017). Non-compliance in national parks: An extension of the theory of planned behaviour model with pro-environmental values. Tourism Management, 59, 123-127.

Hair, J. F. J., Black, W. C., Babin, B. J., \& Anderson, R. E. (2010). Multivariate data analysis: A global perspective (7th ed.). USA: Pearson.

Hair, J. F. J., Hult, G. T. M., Ringle, C. M., \& Sarstedt, M. (2014). A primer on partial least squares structural equation modeling (PLS-SEM). UK: Sage.

Han, H. (2014). The norm activation model and theory-broadening: Individuals' decision-making on environmentally-responsible convention attendance. Journal of Environmental Psychology, 40, 462-471.

Han, H. (2015). Travelers' pro-environmental behavior in a green lodging context: Converging value-belief-norm theory and the theory of planned behavior. Tourism Management, 47, 164-177.

Han, H. \& Hwang, J. (2015). Norm-based loyalty model (NLM): Investigating delegates' loyalty formation for environmentally responsible conventions. International Journal of Hospitality Management, 46, 1-14.

Han, H., Hwang, J., Kim, J. \& Jung, H. (2015). Guests' pro-environmental decision-making process: Broadening the norm activation framework in a lodging context. International Journal of Hospitality Management, 47, 96-107.

Han, H., Jae, M., \& Hwang, J. (2016). Cruise travelers' environmentally responsible decision-making: An integrative framework of goal-directed behavior and norm activation process. International Journal of Hospitality Management, 53, 94-105.

Harland, P., Staats, H., \& Wilke, H. A. M. (1999). Explaining pro-environmental intentions and behavior by personal norms and the theory of planned behavior. Journal of Applied Social Psychology, 29, 2505-2528.

Harland, P., Staats, H., Wilke, H. A. M. (2007). Situational and personality factors as direct or personal norm mediated predictors of pro-environmental behavior: Questions derived from norm-activation theory. Basic and Applied Social Psychology, 29(4): 323-334.

Kaiser, F. G., \& Shimoda, T. A. (1999). Responsibility as a predictor of ecological behaviour. Journal of Environmental Psychology, 19(3), 243-253.

Kiatkawsin, K, \& Han, H. (2017). Young travelers' intention to behave pro-environmentally: Merging the value-beliefnorm theory and the expectancy theory. Tourism Management, 59, 76-88.

Kim, E., Ham, S., Yang, I. S., \& Choi, J. G. (2013). The roles of attitude, subjective norm, and perceived behavioral control in the formation of consumers' behavioral intentions to read menu labels in the restaurant industry. International Journal of Hospitality Management, 35, 203-213.

Kim, Y. J., Njite, D., \& Hancer, M. (2013). Anticipated emotion in consumers' intentions to select eco-friendly restaurants: Augmenting the theory of planned behavior. International Journal of Hospitality Management, 34, 255-262.

Kim, Y., \& Han, H. (2010). Intention to pay conventional-hotel prices at a green hotel a modification of the theory of planned behavior. Journal of Sustainable Tourism, 18(8), 997-1014.

Klockner, C. A., \& Friedrichsmeier, T. (2011). A multi-level approach to travel mode choice - How person 
Zhang, H., Huang, R., Zhang, Y., Buhalis, D., 2020, Cultural ecosystem services evaluation using geolocated social media data: a review, Tourism Geographies https://doi.org/10.1080/14616688.2020.1801828

characteristics and situation specific aspects determine car use in a student sample. Transportation Research Part F: Traffic Psychology and Behaviour, 14 (4), 261-277.

Lin, T. P. (2010). Carbon dioxide emissions from transport in Taiwan's national parks. Tourism Management, 31(2), 285-290.

Luo, F., Becken, S. \& Zhong, Y. (2018). Changing travel patterns in China and 'carbon footprint' implications for a domestic tourist destination. Tourism Management, 65, 1-13.

Mace, B. L., Marquit, J. D., \& Bates, S. C. (2013). Visitor assessment of the mandatory alternative transportation system at Zion National Park. Environmental Management, (5), 1271-1285.

Mackett, R. L. (2003). Why do people use their cars for short trips? Transportation, 30(3), 329-349.

Martín-Cejas, R. R. (2015). The environmental impact caused by road access to Timanfaya Natural Park on Lanzarote Island. Transportation Research Part D: Transport and Environment, 41, 457-466.

Monz, C., D'Antonio, A., Lawson, S. Barber, J., \& Newman, P. (2016). The ecological implications of visitor transportation in parks and protected areas: Examples from research in US National Parks. Journal of Transport Geography, 51: 27-35.

Nakamura, H., \& Abe, N. (2016). Tourist decisions in renting various personal travel modes: A case study in Kitakyushu City, Japan. Tourism Management, 55, 85-93.

Nègre, J.\& Delhomme, P. (2017). Drivers' self-perceptions about being an eco-driver according to their concern for the environment, beliefs on eco-driving, and driving behavior. Transportation Research Part A: Policy and Practice, 105, 95-105.

Nilsson, M., \& Kuller, R. (2000). Travel behaviour and environmental concern. Transportation Research, 5D, 211234.

Riggs, W. (2017). Painting the fence: Social norms as economic incentives to non-automotive travel behavior. Travel Behaviour and Society, 7, 26-33.

Rivis, A., \& Sheeran, P. (2003). Descriptive norms as an additional predictor in the theory of planned behaviour: A meta-analysis. Current Psychology: Developmental, Learning, Personality, Social, 22, 218-233.

Schwartz, S. H. (1977). Normative influence on altruism. In L. Berkowitz (Ed.), Advances in experimental social psychology, Vol. 10 (pp. 221-279). New York: Academic Press.

Schwartz, S. H., \& Howard, J. A. (1981). A normative decision-making model of altruism. In: Rushton, J.P., Sorrentino, R.M. (Eds.), Altruism and Helping Behavior. Erlbaum, Hillsdale, pp. 89-211.

Siponen, M., \& Vance, A. (2010). Neutralization: New insights into the problem of employee information systems security policy violations. MIS Quarterly, 34(3), 487-502.

Stern, P. C. (2000). New Environmental Theories: Toward a coherent theory of environmentally significant behavior. Journal of Social Issues, 56 (3) :407-424.

Sykes, G., \& Matza, D. (1957). Techniques of neutralization: A theory of delinquency. American Sociological Review, 22, 664-670.

Transport Administration of Public Security Ministry. (2017). Registered vehicles amount in first quarter of 2017 in China. http://www.mps.gov.cn/n2255040/n4908728/c5682934/content.html.

Triandis, H. C. (1977). Interpersonal behavior. Monterey, CA: Brooks/Cole.

Triandis, H. C. (1980). Values, attitudes, and interpersonal behavior. In H. E. Howe \& M. M.

Page (Eds.), Nebraska Symposium on Motivation 1979 (pp. 195-259). Lincoln: University of Nebraska Press.

Thøgersen, J. (2006). Norms for environmentally responsible behaviour: An extended taxonomy. Journal of Environmental Psychology, 26, 247-261.

Uba, C. D., \& Chatzidakis, A. (2016). Understanding engagement and disengagement from pro-environmental 
Zhang, H., Huang, R., Zhang, Y., Buhalis, D., 2020, Cultural ecosystem services evaluation using geolocated social media data: a review, Tourism Geographies https://doi.org/10.1080/14616688.2020.1801828

behaviour: The role of neutralization and affirmation techniques in maintaining persistence in and desistance from car use. Transportation Research Part A: Policy and Practice, 94, 278-294.

Untaru, E. N., Ispas, A., Candrea, A. N., Luca, M., \& Epuran, G. (2016). Predictors of individuals' intention to conserve water in a lodging context: The application of an extended Theory of Reasoned Action. International Journal of Hospitality Management, 59, 50-59.

Wells, V. K., Taheri, B., Gregory-Smith, D., \& Manika, D. (2016). The role of generativity and attitudes on employees home and workplace water and energy saving behaviours. Tourism Management, 56, 63-74.

Whitmarsh, L., \& O'Neill, S. (2010). Green identity, green living? The role of pro-environmental self-identity in determining consistency across diverse pro-environmental behaviours. Journal of Environmental Psychology, 30, 305-314.

Wolf, I. D., \& Croft, D. B. (2010). Minimizing disturbance to wildlife by tourists approaching on foot or in a car: A study of kangaroos in the Australian rangelands. Applied Animal Behaviour Science, 126(1-2), 75-84.

Wu, P. L., Yeh, S. S., \& Woodside, A. G. (2014). Applying complexity theory to deepen service dominant logic: Configural analysis of customer experience-and-outcome assessments of professional services for personal transformations. Journal of Business Research, 67(8), 1647-1670.

Yu, H., Chen, T., Zhong, L. S., \& Zhou R. (2017). Functional zoning of the Qianjiangyuan National Park System Pilot Area. Resources Science, 2017, 39(1): 20-29.

Zhang, H. M., Wu, Y., \& Buhalis, D. (2018). A model of perceived image, memorable tourism experiences and revisit intention. Journal of Destination Marketing \& Management, http://dx.doi.org/10.1016/j.jdmm.2017.06.004.

Zhang, X. J., Geng, G. J., \& Sun, P. (2017). Determinants and implications of citizens' environmental complaint in China: Integrating theory of planned behavior and norm activation model. Journal of Cleaner Production, 166, 148-156.

Zhang, Y., Wang, Z., \& Zhou, G. (2013). Antecedents of employee electricity saving behavior in organizations: an empirical study based on norm activation model. Energy Policy, 62, 1120-1127. 